\title{
Factors Related to the Quality of Antenatal Care Based on The Complete Scope of the Examination of Pregnant Women in the Health Center at Palopo City
}

\author{
Dian Furqani1 ${ }^{*}$, Nuraerni Semagga ${ }^{2}$ \\ 1) DIII Pharmacy Study Program, STIKES Bhakti Pertiwi Luwu Raya Palopo \\ 2) DIII Midwifery Study Program, STIKES Bhakti Perwiti Luwu Raya Palopo \\ dianfurqanihamdan@gmail.com \\ DOI: http://doi.org/10.29080/jhsp.v3i3S.294
}

\begin{abstract}
Keywords
Antenatal Care

Quality;

Maternal

Knowledge;

Pregnancy Age;

Parity; Maternal

Characteristics;

Welfare Status

Abstract

This study aims to see the factors that influence the quality of Antenatal Care in the City of Palopo; the type of design used is analytical descriptive with the Cross-Sectional Study approach. Samples from this study were all pregnant women based on 1, 2 and 3thtrimester pregnancy age, and 3 who were lived at the research location as many as 154 people who conducted inspection visits from January to March 2018. The results showed that the average age of the mother was 20 years. In the research statistically interconnected variables are maternal knowledge showed p-value (0.000). There are several variables have statistical significance, but there are differences in the percentage between the classification of each variabels as for the quality of Antenatal care associated with parity, maternal characteristics (age, education and occupation), antenatal care in each of the 1.2 trimester, and 3. Service access and economic welfare status, where each variable has a p-value> 0.005. The study expects that a health program should not look the quantity of maternal pregnancy visits, but pay attention to the examination checks received at each gestational age. We hope to encourage mothers to be more active in paying attention to the examinations that will be accepted based on their gestational age so that good health services and of recipients of services occur.
\end{abstract}

\section{Introduction}

Antenatal care (ANC) is one of the recommended interventions to reduce maternal and infant mortality (1). The maternal mortality rate (MMR) in Indonesia is still quite high from the ASEAN region of 228 / 100,000KH. Maternal health services are essential for maternal, perinatal, and infant life. The high rates of maternal and neonatal mortality are related to the inadequate and low quality of maternal services, including ANC services, the quality of health workers at birth and after childbirth (2). This causes to achieve the SDGs goals, and efforts are needed to improve service quality.

Quality and outcome improvement are also aligned with the objectives of the global strategy where optimization of the scope of services for reproduction, new borns and children's health must be a necessity (3). Improved service coverage with quality must be carried out in order to reduce maternal mortality. For example, in Tanzania, 94\% of women visited the ANC and 54\% visited the ANC with four visits. However this is precisely in line with the increase in maternal mortality (4). This shows that the quantity of coverage has not fully demonstrated the quality of service.

In India, the results of the national survey show that the program of providing incentives to mothers and health institution workers as an increase in service coverage (5). Has not been matched by efforts to monitor and improve the quality services so an unclear survival of mothers and infants (6).

Based on the previous explanation, it is known that improving health services has not been able to reduce maternal and child mortality so that adequate intervention is needed. Two interventions can be done to reduce the mortality rate, namely Antenatal Care (ANC) services and delivery services (during labor and birth). The essence of ANC is to prepare births for women and make them parents, prevent problems in women, pregnant women, and babies by early detection, eradication and management of problems that affect mothers and babies during pregnancy (7).

Inadequate ANC services, both coverage and quality, will provide poor pregnancy outcomes (8). The use of ANC services varies between countries based on the lack of use of ANC services for pregnant women 
in Asian and African countries with low income (9). In a country, the use of ANC services is different in maternal age, education, employment, family income, parity, place of residence, costs and availability of health facilities (10).

In Indonesia, pregnant women can get ANC services in various health facilities, namely Puskesmas (Community Health Centers, Posyandu (integrated service posts) / Polindes, Hospitals, Maternity Centers, Doctors / Clinical Practices and midwives practice. Health facilities are provided to increase service coverage health of pregnant women (11). Based on Riskesdas, in 2013, almost all pregnant women in Indonesia (95.4\%) had performed prenatal care (K1), and the frequency of pregnancy at least 4 times during the pregnancy period was 83.5 percent. As for the coverage of the first pregnancy checkup in the first trimester is 81.6 percent and ANC 1-1-2 or K4 frequency (at least 1 time in the first trimester, at least 1 time in the second trimester and at least 2 times in trimester 3 ) at 70.4 percent. However, this shows that the high coverage has not fully demonstrated the quality of ANC services.

Based on the results of Riskesdas in South Sulawesi, 2014 Puskesmas / Pustu became the place most visited by pregnant women in prenatal care (51.1\%), midwife practice (17.4\%), and Poskesdes / Polindes $(10.6 \%)$. The puskesmas category by region is divided into urban health centers, rural areas and remote and very remote areas (12).

\section{Methods}

This research is correlational research. With a cross-sectional approach, where information is collected and examined only on a particular symptom and time span. Where there are 12 health center that are the location of the study, including Wara, Wara Utara,Wara Utara Kota Wara Selatan, Wara Barat, Mungkajang, Sendana, Pontap, Benteng,Bara Permai, Maroangin andPadang Lambe that will be carried out during March 16 to August 162018 .

\section{Results}

The results of the study were obtained from data collection and data analysis processes that will be displayed in this chapter. Characteristics of respondents (age, last education, occupation) and determinants that are thought to affect the quality of antenatal care during maternal pregnancy.

1. Respondent Characteristics

Table 1. Respondent Distribution Based on groups of pregnant women

\begin{tabular}{cccc}
\hline & & \multicolumn{2}{c}{ Mean } \\
Age group & $\mathrm{N}$ & $\%$ & SD \\
\hline $15-19$ & 24 & 19.7 & \\
$20-24$ & 68 & 29.5 & 2.66 \\
$25-29$ & 31 & 25.4 & 1,237 \\
$30-34$ & 19 & 15.6 & \\
$\geq 35$ & 12 & 9.8 & \\
Total & 154 & 100.0 & \\
\hline
\end{tabular}

Source: Primary Data, 2018

Table 1 shows that most respondents in the 20-24 year age group were 68 respondents (29.5\%) with a standard deviation of 1,237 it means about the distribution of data on age groups.

Table 2. Distribution of Respondents Based on the work of pregnant women

\begin{tabular}{ccc}
\hline Mother's work & $\mathrm{n}$ & $\%$ \\
\hline Housewife & 116 & 95.1 \\
Civil servant & 17 & 1.6 \\
Farmer & 21 & 3.3 \\
Total & 154 & 100.0 \\
\hline
\end{tabular}

Source: Primary Data, 2018

Table 2 shows that the work of the most respondents is housewives, namely $116(95.1 \%)$ and 17 $(1.6 \%)$ respondents are civil servants and there are 21 (3.3\%) mothers working as farmers. 
Table 3. Distribution of Respondents Based on Education Levels of Pregnant Women Latest Education Level $\mathrm{n} \quad \%$

\begin{tabular}{lcc}
\hline Not completed in primary school & 21 & 30.5 \\
Graduated from elementary school & 17 & 15.0 \\
Graduated from junior high school & 84 & 41.0 \\
Graduated from high school & 15 & 3.5 \\
Graduated from College & 17 & 15.0 \\
\multicolumn{1}{c}{ Total } & 154 & 100.0 \\
\hline
\end{tabular}

Source: Primary Data, 2018

Table 3 shows that generally, respondents have a level of education not graduating from junior high school which is 84 respondents (41.0\%), then graduated from elementary school and graduated from college having the same number of 17 respondents $(15.0 \%)$.

Table 4. Distribution of Respondents Based on the Place of Examination for Pregnant Women

\begin{tabular}{lcc}
\hline \multicolumn{1}{c}{ Checkpoint } & $\mathrm{n}$ & $\%$ \\
\hline Posyandu & 55 & 41.0 \\
Pustu & 30 & 25.0 \\
Puskesmas & 21 & 10.5 \\
Clinic / Midwife Practice & 16 & 5.0 \\
Pustu and Obygn Practice & 17 & 6.0 \\
Pustu, PKM, and Hospitals & 10 & 3.5 \\
Pustu and Hospital $\quad$ Total & 5 & 100.0 \\
\end{tabular}

Source: Primary Data, 2018

Table 4 shows that Posyandu is the most inspected place for respondents to check their pregnancy, which is $55(41.0 \%)$ and there are around $5(1.6 \%)$ respondents who choose to have their pregnancies checked more than one place, namely Clinic / Midwife Practice, Obgyn Practice, and Hospital.

Table 5. Pregnancy Age-Based Respiratory Distribution

\begin{tabular}{lll}
\hline Mother's Pregnancy Age & N & $\%$ \\
\hline 1st trimester & 38 & 14.9 \\
Trimester 2 & 64 & 52.5 \\
Trimester 3 & 52 & 32.6 \\
Total & 154 & 100.0
\end{tabular}

Source: Primary Data, 2018

Table 5 shows that the highest gestational age in the second trimester is the highest maternal gestational age of $64(52.5 \%)$ and there are $52(32.6 \%)$ in the third trimester and $38(14.9 \%)$ in the first trimester.

2. Relationship Of Variables With Quality Antenatal Care

The bivariate analysis aims to look at the relationship among the Independent variables (maternal knowledge, maternal characteristics, community economic stautus, access to health services, checkpoints, and maternal reproductive status) to the quality of antenatal care during pregnancy by looking at the $\mathrm{p}<0.005$. The results of the analysis can be seen in the table below:

Table 6. Relationship of Mother Knowledge About Components of Examination with Antenatal Care Quality at Palopo City Health Center

Mother's
Knowledge

Source: Primary Data, 2018

The results of statistical tests by looking at the $\mathrm{p}$ value $<0.000$ shows that there is a significant relationship between maternal knowledge about the components of the examination and the quality of Antenatal Care. As many as $40.3 \%$ of mothers with less knowledge of poor quality examinationthis 
grouping of maternal knowledge is based on the mother's response when asked about the component of antenatal care they will receive based on their gestational age. Only $29.4 \%$ are mothers with sufficient knowledge of the components ANC examination according to gestational age obtains good ANC quality.

Table 7. Relationship of Mother Characteristics (age, education, occupation) with Antenatal Care Quality at Palopo City Health Cente

\begin{tabular}{|c|c|c|c|c|c|c|c|}
\hline \multirow[t]{2}{*}{ Mother Characteristics } & \multicolumn{4}{|c|}{ ANC Quality Check } & \multirow[t]{2}{*}{ Total } & \multirow[t]{2}{*}{$\%$} & \multirow[t]{2}{*}{$\mathrm{p}$} \\
\hline & Less & $\%$ & Well & $\%$ & & & \\
\hline \multicolumn{8}{|l|}{ Age } \\
\hline$<20$ years & 16 & 14.0 & 20 & 16.0 & 36 & 30.0 & \\
\hline $20-25$ years & 66 & 40.0 & 40 & 22,9 & 106 & 62.9 & 0.605 \\
\hline$>35$ years & 9 & 6.6 & 3 & 1.5 & 12 & 8.1 & \\
\hline Education & & & & 17.0 & 91 & 59.6 & 0.681 \\
\hline Low & 68 & 42.6 & 23 & 22.4 & 63 & 40.4 & \\
\hline High & 23 & 18.0 & 40 & & & & \\
\hline Work & & & & 17.4 & 110 & 75.5 & 0.600 \\
\hline Does not work & 88 & 58,1 & 28 & 22.0 & 39 & 24.5 & \\
\hline Work & 4 & 2.5 & 35 & & & & \\
\hline
\end{tabular}

Source: Primary Data, 2018

The results of statistical tests by looking at the p-value on each variable of maternal characteristics, namely education, occupation and education $(0.605 ; 0.681 ; 0.600)$ showed no significant relationship between maternal characteristics with Antenatal Care quality, as many as 66 $(40.0 \%)$ mothers at the age of 20-25 years received poor quality examinations, and mothers with low education status were 68 (42.6\%) mothers received low quality examinations, and so did 88 respondents who did not work (58.1\% ) obtaining poor quality checks.

Table 8. Relationship of Check Points with Antenatal Care Quality at the Palopo City Health Center

\begin{tabular}{|c|c|c|c|c|c|c|c|}
\hline \multirow[t]{2}{*}{ Checkpoint } & \multicolumn{4}{|c|}{ Quality of Examination } & \multirow[t]{2}{*}{ Total } & \multirow[t]{2}{*}{$\%$} & \multirow[t]{2}{*}{$\mathrm{P}$} \\
\hline & Less & $\%$ & Well & $\%$ & & & \\
\hline One place & 61 & 40.2 & 20 & 10.0 & 65 & 50.2 & \\
\hline \multicolumn{8}{|l|}{ More than one } \\
\hline Total & 26 & 10.1 & 43 & 25.2 & 89 & 45.3 & 0.648 \\
\hline & 91 & 60.6 & 63 & 39.4 & 154 & 100.0 & \\
\hline
\end{tabular}

Source: Primary Data, 2018

The results of statistical tests by looking at the value of $p=0.648$ showed no significant relationship between the examination place and the quality of antenatal care, as 61 (40.2\%) mothers who did the examination only at one place received poor quality examination. This was because there were several items Examinations that are not available in the library or in the Posyandu are like an ultrasound device to see the development of the growing fetus. In addition, sometimes there are some mothers who ignore the advice of the midwife to carry out a follow-up examination to the Puskesmas.

Table 9. Relationship of Welfare Status with Antenatal Care Quality at the Palopo City Health Center

\begin{tabular}{|c|c|c|c|c|c|c|c|}
\hline \multirow[t]{2}{*}{ Welfare Status } & \multicolumn{4}{|c|}{ Quality of Examination } & \multirow[t]{2}{*}{ Total } & \multirow[t]{2}{*}{$\%$} & \multirow[t]{2}{*}{$\mathrm{P}$} \\
\hline & Less & $\%$ & Well & $\%$ & & & \\
\hline Poor & 41 & 23.2 & 20 & 10.0 & 65 & 33.2 & 0.059 \\
\hline Rich & 60 & 40.1 & 43 & 23.2 & 89 & 45.3 & \\
\hline Total & 91 & 60.6 & 63 & 39.4 & 154 & 100.0 & \\
\hline
\end{tabular}

Source: Primary Data, 2018

The results of the statistical test by looking at $\mathrm{p}=0.059$ showed that there was no relationship between welfare status with Antenatal Care quality. This grouping of welfare status is seen based on the value of the asset index. There were $60(40.1 \%)$ mothers with rich welfare status who received poor quality examination because their knowledge was lacking about the examination component Antenatal Care that must be obtained during pregnancy, while mothers with poor welfare status 41 
$(23.2 \%)$ this is because mothers do not use health insurance cards for treatment or pregnancy checkups, some mothers do not even know their rights by using a health insurance card.

\section{Discussion}

The quality of antenatal care received by pregnant women in the Palopo City Health Center in this study obtained results that out of 154 respondents, 63 (39.4\%) mothers obtained good quality according to their gestational age. This was influenced by maternal knowledge about the components of the examinationt, parity, and family economic status. This research shows that quality determinants of Antenatal care in the city of Palopo based on bivariate and multivariate analysis obtained maternal knowledge about components is the most influential determinant. This is because most respondents are mothers with primapara parity status and maternal age when pregnant in the young age category, so that knowledge about the importance of antenatal care examination is very lacking (13).

Antenatal care examination visits are also affected by family welfare status, even though in this study there is no statistically significant relationship between statuses Quartile based economy which is categorized into two, namely rich and poor group of Antenatal care quality, however see the percentage difference that there are variations in place selection examination between rich and poor groups in doingAntenatal care visit .

About $1.6 \%$ of the group mothers with rich economic status and have an education status lastly high perform antenatal care at more than one place to get more antenatal care adequate. Research that was done by Titaley et al.get results that a higher wealth index does not associated with a reduced likelihood of complications pregnancy but higher education is found to be associated with decreased likelihood of pregnancy complications (8). Especially for hemoglobin examination which is prioritized in trimester the first was found to be significantly related to the opportunity lower than pregnancy complications in the mother.

Based on the results of the study, mothers who only checked their pregnancies in Pustu and Posyandu even though the distance from the examination place was easier to reach, but there were components that were not given due to limited examination tools, and the tendency of pregnant women to only have their pregnancies checked in one place for economic reasons because not all mothers have cards good health insurance (KIS) provided by the government and independent BPJS.

ANC plays an important role in empowering women to seek postnatal care. During the visit ANC, women are told about signs of birth complications children and poor health in their babies. as a result they are able to recognize these danger signs and looking for the right treatment at the right time. Mother must can search for immunizations for their children and monitor their growth through health facilities (14).

\section{Conclusion and Suggestion}

Determinants of maternal knowledge of the components of ante natal care at Palopo City health centers relate to the mother's last level of education. Lack of experience and knowledge about pregnancy examinations affects the quality of Antenatal care received. The selection of examination sites is influenced by the distance to access services because most of the mothers' jobs are housewives so that the average mother chooses Pustu as an antenatal care checkpoint because it is easier to reach when walking or riding public transportation.

\section{References}

1. Ejigu T, Woldie M, Kifle Y. Quality of antenatal care services at public health facilities of Bahir-Dar special zone, Northwest Ethiopia. BMC Health Services Research. 26 Oktober 2013;13(1):443.

2. Lerberghe WV. Make every mother and child count. The World Health Report; 2005.

3. Bauer MS, Damschroder L, Hagedorn H, Smith J, Kilbourne AM. An introduction to implementation science for the non-specialist. BMC Psychol. Desember 2015;3(1):32.

4. Pembe AB, Urassa DP, Carlstedt A, Lindmark G, Nyström L, Darj E. Rural Tanzanian women's awareness of danger signs of obstetric complications. BMC Pregnancy Childbirth. Desember 2009;9(1):12.

5. Fagbamigbe AF, Idemudia ES. Assessment of quality of antenatal care services in Nigeria: evidence from a population-based survey. Reprod Health. 18 September 2015;12:88.

6. Murray SF, Hunter BM, Bisht R, Ensor T, Bick D. Effects of demand-side financing on utilisation, experiences and outcomes of maternity care in low- and middle-income countries: a systematic review. BMC Pregnancy Childbirth. Desember 2014;14(1):30.

7. Lincetto O, Mothebesoane-Anoh S, Gomez P, Gomez P. Opportunities for Africa's Newborns. 2010.

8. Titaley CR, Dibley MJ, Roberts CL. Factors associated with underutilization of antenatal care services in Indonesia: results of Indonesia Demographic and Health Survey 2002/2003 and 2007. BMC Public Health. Desember 2010;10(1):485. 
9. Zanconato G, Msolomba R, Guarenti L, Franchi M. Antenatal care in developing countries: The need for a tailored model. Seminars in Fetal and Neonatal Medicine. Februari 2006;11(1):15-20.

10. Birmeta K, Dibaba Y, Woldeyohannes D. Determinants of maternal health care utilization in Holeta town, central Ethiopia. BMC Health Serv Res. Desember 2013;13(1):256.

11. Mantao E, Suja MDD. Tingkat Pendidikan Ibu Dengan Kepatuhan Antenatal Care Pada Perdesaan Dan Perkotaan Di Indonesia. Dalam Yogyakarta: Universitas Gadjah Mada / Public Health / Maternal and Child Health; 2018.

12. Riset Kesehatan Dasar Indonesia. Pedoman Pelayanan Antenatal Terpadu. Jakarta: Public Health Center; 2015.

13. Fekadu M, Regassa N. Skilled delivery care service utilization in Ethiopia: analysis of rural-urban differentials based on national demographic and health survey (DHS) data. Afr Health Sci. Desember 2014;14(4):974-84.

14. Fariji AA. Faktor yang berhubungan dengan pemanfaatan kunjungan antenatal care di Purwakarta. [Jakarta]: Universitas Indonesia; 2008. 